\title{
The Implementation of the Principle of Justice in Post-nuptial Agreement towards Mixed Marriage: Hope or Challenge?
}

\author{
Umar Haris Sanjaya ${ }^{1}$ \\ ${ }^{1}$ Faculty of Law, Universitas Islam Indonesia \\ Doctoral Student at Faculty of Law, Universitas Airlangga Surabaya, Indonesia \\ umarharis@uii.ac.id
}

\begin{abstract}
Introduction to the Problem: this research focuses on the actors of mixed marriage in Indonesia who have hope at the practice level. The hope arises from the Constitutional Court decision No. 69/VII/PUU/2015, which allows the formation of an asset separation agreement after the marriage takes place (post-nuptial agreement). The decision is followed up by two Circular Letters of relevant ministries: one is from the Ministry of Home Affairs No. 472.2/5876/Dukcapil, which guarantees that post-nuptial agreement is allowed in the Civil Registry (Dukcapil); as well as the one from Directorate Generals of Community Guidance under the Ministry of Religion No. B.2674/DJ/III/KW.00/9/2017. By enacting these instruments, Indonesia facilitates a hope to the mixed marriage, which is the hope of the ownership of the assets.

Objectives of the Study: To identify the implication of the Constitutional Court decision No. 69/VII/PUU/2015 in practice, in lieu with the implication of the Circular Letters of the Ministry of Home Affairs No. 472.2/5876/Dukcapil and Directorate Generals of Community Guidance under the Ministry of Religion No. B.2674/DJ/III/KW.00/9/2017; also, to review the possibilities of those decisions and Circular Letters in the perspective of Indonesian family law, would it be a hope or a challenge?
\end{abstract}

Methodology: This is normative-juridical research, which implements a doctrinal approach to analyze the problems.

Findings: Post-nuptial agreement is allowed and having legal implications to the parties to the marriage bond. Ministry of Home Affairs and the Ministry of Religion have facilitated the Constitutional Court decision by enacting their respective Circular Letters to guide the civil registry officials in responding to the post-nuptial agreement. Paper Type: Research Article Keywords: Mixed Marriage; Ownership of Asset; Post-nuptial Agreement

\section{Introduction}

Issues in international private law heat up in the context of family law (Lemmings, 1996). For example, actors doing mixed marriage are increasing year by year. It means that international matters are not limited in the matters of business, political, 
or public matters, but also to marriage. Marriage is one of the matters which brings Indonesia into the global era (Fauzan, 2000). Mixed marriage is the marriage bond between two parties with different nationalities, which one of the parties in a mixed marriage is an Indonesian citizen (Muttaqin, 2003). In Indonesia, marriage is regulated under Marriage Law No. 16 of 2019 on the Amendment of Law No. 1 of 1974 (hereinafter referred as 'Marriage Law'), which defines marriage as the sacred relationship of body and soul to build a family between a man and a woman for a long time (forever) based on the faith to God (Ismail et al., 2000). Mixed married comprises of people from different nations and races. Thus, the law on mixed marriage adopts the principles of law in international private law (Gautama, 1995). In international private law, the rights of people (vested rights) are not limited to the property or assets only (vermogen rechten), but also in the law of family or law of person (Saragih, 1974).

In Indonesia, the law of marriage recognizes the unification of properties after marriage. This unification became the legal consequence for the parties which celebrate and register their marriage in Indonesia under the Indonesian marriage law. It means that every property acquired during the marriage is owned by both parties (Amruzi, 2014). It is regulated in Article 35 of the Mariage Law. This consequence is absolute except if the marriage bond is broken (divorce) (Harahap, 2007) or if there is an exception, then it can be deviated (Tjitrosudibio, 2009). The exception is by making a pre-nuptial agreement that cancels the unification of assets that belong to both parties.

The unification of assets in mixed marriage gives potential problems in line with the ownership of the assets. Those potential problems are in the context of prohibition for a foreign citizen to obtain land ownership. It is stated in Article 21 of Land Law No. 5 of 1960 which states that foreigner and Indonesian citizen who has other nationality must release their land ownership. It is also applied in the context of inheritance practice if the inheritance is conducted without will. It means that foreign citizens may have temporary land ownership (HGB, HGU). Thus, the foreign nationals do not have any right to get a freehold of land ownership. That prohibition in the freehold of land ownership will raise the potential problem between mixed marriage actors in Indonesia because one of the parties has different rights. Those differences are: (1) in the land ownership, (2) unification of assets, which would not exist if one of the marriage parties (the foreigner) did not have rights in land ownership. The impact is that the other party (the Indonesian national) is hence prohibited from owning or buying the land.

The best way for actors of mixed marriage is by making a pre-nuptial agreement. It is the easiest solution offered to the parties of mixed marriage in Indonesia. Both need to pay attention to the limitation in a mixed marriage in terms of ownership, especially for the foreigner. Thus, it is the best suggestion in regards 


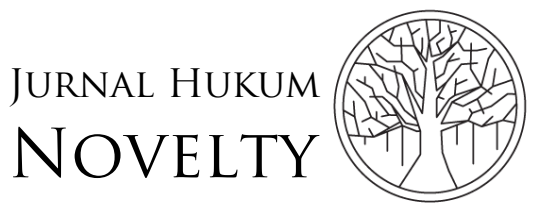

Volume 12, Issue 02, 2021, pp. 282-294

P-ISSN: 1412-6834

E-ISSN: 2550-0090

to preventing another couple makes the same mistake in the future. In fact, there are actors of mixed marriage who did not commit in any pre-nuptial agreement.

There is a case of an Indonesian Muslim woman named Pipit April Yanti and a Taiwanese man named Liou Jih Sheng, who is also a muallaf (someone who has converted to Islam), both celebrate and register their marriage under Indonesian law. Both are married in the Office of Religious Affairs on the 30 $0^{\text {th }}$ of April 2017 in Tamansari Village, Lelea, Indramayu District, West Java. The marriage is legitimate, valid, fulfills all requirements based on Article 2 point (2) of Indonesian Marriage Law. It means the marriage is legitimate in the eyes of the religion and before the state. It is also proven by Certificate of Marriage No.0166/001/IV/2017 released by Indramayu's Office of Religious Affairs (Mubarok, 2018). After the marriage, the wife intended to buy a house at Permata Regency Indramayu on the $6^{\text {th }}$ of May 2017. In the first meeting between Pipit and Permata Regency, both committed to a Letter of Understanding on sale and purchase of house agreement under KPR (installment) mode. In the second meeting, the Letter of Understanding was nullified by Permata Regency, and they argued that Pipit is married to a foreigner. Foreigner is prohibited from buying a house based on Article 36 point (1) of Land Law and Article 1 of Marriage Law. The argumentation was explained by Permata Regency as the interpretation of Marriage Law and Land Law. Thus, Pipit and her husband canceled out the plan as they could not be owning the house. The nationality principle in the Agrarian Law of Indonesia prohibits foreigners from owning land, even though they are married to an Indonesian national. It is due to the consideration that foreigners will purchase the land by borrowing the name of their spouse through marriage (Anjasari, 2018). It means that mixed marriage couples at that time suffered losses because of the lack of regulation that prohibited it.

Article 28 Point H clause (4) of the Indonesian Constitution of 1945 states that every Indonesian national has the right to ownership. But it is not applicable towards Indonesian national who is married to a foreigner, because of the unification of assets between them. Unification of assets includes as the point of prohibition according to Article 21 point (3) and Article 26 point (2) of the Land Law for mixed marriage couples in Indonesia. On 19 th of May 2017, Constitutional Court accepts the judicial review of Article 29 clause (1), (3), and (4) of the Marriage Law by Constitutional Court Decision No: 69/PUU/XIII/2015. The Constitutional Court Decision gives an additional consideration in each revised clause. First, in Article 29 clause (1), the norm is revised by additional sentence of "parties can submit or make writing agreement based on mutual consent between two parties before marriage or during marriage and it is ratified by marriage registrar or public notary, and it is applicable to the third party if it is involved." It means that Article 29 clause (1) should be interpreted that a marriage agreement can be made during the marriage, and also it would be made by a public notary. Second, in Article 29, clause (3) that marriage agreement comes into force since the marriage takes 
place, except if it was not determined in the agreement. Third, in Article 29, clause (4) that the marriage agreement determines any assets in a marriage relationship or any other, it cannot be changed or revoked, except if both parties agreed to revise or revoke, and the revision or revocation do not harm the third party. It means that the third parties involved are the marriage registrar, public notary, and other third parties. The author criticizes that additional words in Article 29 clause (1), which states the marriage agreement made by parties "before or during the marriage," will raise any other potential problem in family law itself, even though this revision is giving a solution for other problems.

Other considerations in revising the Marriage Law which gives solutions are:

1. Indonesia nationals in mixed marriage can make a marriage agreement to separate their assets.

2. This solution represents the principle of freedom of contract, in which parties in the contract should not be limited by time. It presents in the word "before". Some may have an opinion that marriage agreements should not only be "before" but also "during" the marriage. Basically, it represents Article 28E clause (2) of the Indonesian Constitution of 1945.

However, several reasons arise from the Constitutional Court Decision, which gives potential problems regarding the word "during":

1. The third party who is already involved with one of the marriage parties may suffer damage or loss due to the unclear inventories.

2. The said inventories are obligations, debts, or any business contracts which have been committed by one of the marriage parties; note that Indonesian Marriage Law applies the unification of assets. It will lead to problems if preexisting agreements are based on the unification of assets, which then turns to the separation of assets.

Derived from the reasons mentioned above, differences in understanding will rise. The understanding of the parties who support the Constitutional Court's decision considers that the decision has provided a solution, while the understanding of the opposing parties considers this decision to be problematic in the interpretation of the law.

\section{Methodology}

This research was conducted in Yogyakarta using the methodology juridical and normative study, which means the research applies the principle of law and doctrine to address the study's objectives (Arikunto, 1996). The research is described in a qualitative approach to identify how the law is applied in fact. Thus, the author uses the conceptual and case approaches to answer the objectives of the study (Mamudji, 2005). This research uses primary resources such as the Constitutional Court Decision No. 69/VII/PUU/2015, Circular Letter of the Ministry of Home Affairs No. 472.2/5876/Dukcapil, and Circular Letter of Directorate Generals 
of Community Guidance under the Ministry of Religion No. B.2674/DJ/III/KW.00/9/2017. To support the primary resources, the author interviewed actors of mixed marriage and the registry officer.

\section{Results and Discussion}

\section{Marriage Law in Indonesia Applies the Principle of Unification of Assets}

As we know, Indonesian marriage law applies the concept of the unification in assets. This concept has the consequences that every people who are married under Indonesian law and the marriage is registered in authorized registration are hence committed to the unification of assets soon after the celebration. It means that assets from both parties acquired in the marriage are under communal ownership. This unification is based on Article 35 of the Marriage Law states that all properties obtained during the marriage are registered in Indonesia become communal belonging unless the marriage is dissolved. It means that the authority, control, and form of the assets are to be managed together, including obligation or debt related to the third party if that obligation needs mutual agreement (Sanjaya, 2017). However, not every asset obtained during the marriage is unified directly. There are certain assets that the individual party can manage in the marriage. It happens if the assets are inheritance, gifts, or previously owned. Thus, those assets are fully controlled or managed by the individual party. It will be divided to each party as fair as possible if they agree to divorce, as long as both parties keep their rights towards each other.

The unification of assets concept may deviate if both parties in a marriage relationship have mutual consent to separate the assets. This separation can be performed before the marriage is celebrated, it is commonly named pre-nuptial agreement (Anwar, 1999). However, separation of assets does not eliminate the husband's liability in a marriage relationship to fulfill daily life needs. Thus, separation of assets is a mutual commitment agreed between husband and wife before the marriage takes place in the form of a pre-nuptial agreement. Pre-nuptial agreement deviates from Indonesian Marriage Law. Basically, pre-nuptial agreement to separate the assets in marriage contains as follow:

1. Separation of the pre-existing assets such as the previous owned inheritance, gifts, etc.

2. Separation of the obligation of payment that the individual party has committed to the marriage, such as debt or other obligation, would be the personal liability of the respected party individually.

3. Separation of future moveable or immoveable assets, future income, or other income. Thus, a wife does not need any approval from her husband to control and manage her own assets.

A pre-nuptial agreement should be registered to the authorized official before the marriage is celebrated (Clarke, 2014). In Indonesia, the registration is facilitated by 
the Civil Registrary (Dukcapil) under the Ministry of Home Affairs and the Office of Religion Affairs under the Ministry of Religion. It depends on the religious background of the parties to the marriage. A Moslem should be registered to the Office of Religion Affairs, and non-Muslims should be registered to the Civil Registrary (Timex et al., 2015).

Unification of assets causes damage to mixed marriage actors in Indonesia in terms of their property ownership. Indonesia prohibits the foreigner from having ownership of lands such as a house and other land property. The prohibition is based on Article 21 clause (3) of the Land Law, which gives no chance to the foreigner or even Indonesian national who changes their nationality. It means that mixed marriage actors are hindered from owning assets. This is harmful to mixed marriage actors, especially to Indonesian nationals in the mixed marriage while remaining as an Indonesian national. They cannot have access to own a house or land as Indonesian (Harahap, 2016).

\section{Constitutional Court Decision No. 69/PUU/XII/2015 and the Respond of the Government of Indonesia}

Constitutional Court Decision No. 69/PUU/XII/2015 has a similar historical background with the case of Pipit at Lelea, Indramayu District, West Java. The present case before the Constitutional Court was submitted by Ike Farida as a mixed marriage actor. She is an Indonesian married to a Japanese at the Office of Religion Affairs in Makasar, East Jakarta, with certificate No. 3948/VIII/1995 on 22th in August 1995. The marriage was registered at the Civil Registry of Jakarta with file number $36 / \mathrm{KHS} / \mathrm{AI} / 1849 / 1995 / 1999$ on the $24^{\text {th }}$ of May 1999. She had no pre-nuptial agreement before, and she had never changed her nationality. She chose to be an Indonesian always. She then faced several obstacles to own an apartment under the certificate of Building Rights (Hak Guna Bangunan) because she is married to a foreigner. She was declined to purchase the apartment by the developer. Her contract to purchase an apartment was nulled by the developer when it was known that she was married to a foreigner. It is proven by the two letters No. 214/LGL/CGEPH/IX/2012 on the 17th of September 2012 and No. 267/S/LNC/X/2014/IP on the $8^{\text {th }}$ of October 2014 which nullified the sale and purchase contract. Both letters explained that mixed marriage actors could not be allowed to own an apartment as long as they did not have a pre-nuptial agreement. Further evidence is the certificate of Building Rights from the government. Those nullification letters are strengthened by East Jakarta District Court Decision No. 04/CONS/2014/PN.JKT.Tim on the $12^{\text {th }}$ of November 2014, which has the same purpose. The three denial letters have similar considerations in their content:

1. Indonesian is prohibited from obtaining Building Rights over land or building in mixed marriage based on Article 36 clause (1) of the Land Law.

2. Indonesia applies the unification of assets principle based on Article 35 of the Marriage Law. 
Thus, based on Land Law and Marriage Law, Ike Farida is denied to buy an apartment. There are quite a lot of mixed marriage actors in Indonesia. Several numbers are registered and recorded in Indonesia. It exists and can be proven by the presence of mixed marriage actor association. The association has more than eight hundred members. It means that those mixed marriage actors will probably get the same treatment as Ike Farida (Andriani et al., 2020). The problems of mixed marriage in Indonesia were similar in practice. Generally, they have no pre-nuptial agreement that specifies separating the assets. The absence of a pre-nuptial agreement gives rise to the problems mentioned above. For example, what happened to:

1. Marry Anna Nunn married to an American, having no pre-nuptial agreement

2. Windy Nurhafifah Ouwerling married to a Dutch

3. Muntini Cooper married to an Australian

4. Farida Indriani married to a Bangladeshi

5. Septalita Andini married to a Pakistani

6. Cahriani married to a German

7. Rulita Anggraini married to an American

8. Liem Tony Dwi Soelistyo married to a Chinese with no certificate of birth

9. Juliani Wistrarina Luthan married to a Japanese

10. Alya Hiroko Oni, daughter in a mixed marriage

Those are samples of hundreds of mixed marriage actors in Indonesia. All of them have a similar problem in real life: they have no pre-nuptial agreement to separate their assets (Li, 2014). They are denied to purchase a house or land since the process of the transfer of title. The government responded to the Constitutional Court Decision No. 69/PUU/XII/2015 by enacting: first, Circular Letter of the Ministry of Home Affairs No. 472.2/5876/Dukcapil on the 27th of October 2016. This letter is a response to the request which has been granted by the Constitutional Court, in Article 29 of the Marriage Law, which are:

1. A marriage agreement can be made before or during the marriage in front of a public notary and registered to an authorized official.

2. Procedures and requirements to report the marriage agreement are determined in the letter's appendix.

3. A report of the registration will be issued in the deed.

Thus, government facilitates marriage agreements made during the marriage, Starting from the issuance of the Circular Letter. The second, Directorate General of Islamic Community Guidance under the Ministry of Religion, also responded to the Constitutional Court Decision by issuing Circular Letter No. B.2674/DJ/III/KW.00/9/2017 on the $28^{\text {th }}$ of September 2017. It is similar the Circular Letter No. 472.2/5876/Dukcapil before. Those Circular Letters contain and regulate the procedures to register marriage agreements. The main point from the Letters is that registration of the marriage agreement is allowed before, at the time, and during the marriage. The marriage agreement is legalized by a public notary and registered to the authorized officer in the Ministry of Religion. By the issuance of the two Circular 
Letters from the Ministry of Home Affairs and Ministry of Religion, a marriage agreement is possible to be created before or during the marriage. It is a breath of fresh air to mixed marriage actors in Indonesia, especially for those who did not have a marriage agreement yet.

\section{Hope or Challenge?}

Implementation of Constitutional Court Decision No. 69/PUU/XII/2015 takes place in the form of Circular Letter at the practical level, which are Circular Letter No. 472.2/5876/Dukcapil and No. B.2674/DJ/III/KW.00/9/2017. Those letters are issued by the Ministries, which have the authority in civil and marriage registration in Indonesia. It means that a marriage agreement is available to be registered after the issuance of the Circular Letter. It is hoped to settle any potential problems arising in the unification of assets because they can make a new marriage agreement to separate their assets during the marriage (Budiartha, 2017).

The hope is raised with implementing the Constitutional Court Decision, as it is the one of development in Indonesian family law. There will no longer be a limitation to those who are married to foreigners to make their marriage agreement. Mostly, people will make an agreement to separate the assets if referring to the existing marriage principle in Indonesia (the unification in assets). Actually, Indonesia has done something wise for its citizen. It is in line with Article 28B clause (1) of the Indonesian Constitution of 1945, which states that every person has the right to create a family and continue descendants in a legitimate marriage relationship. It means that marriage is one of the basic human rights, and everything related to marriage should be facilitated. Mixed marriage actors are also entitled to receive basic human rights. At least the basic human rights from Indonesian citizens in a mixed marriage to own the house or land is facilitated after they separate their assets. Thus, the previous problems suffered by mixed marriage actors identified above are settled, hoping that the problems decrease as soon as possible (Hernoko et al., 2018).

Another hope is that the foreigners who are married to an Indonesian and registered in Indonesia do not have to change their nationality to be Indonesian to own a house or land. They can do the post-nuptial agreement to separate their ownership. Thus, the house which is purchased will be owned by their Indonesian spouse. It must be done if the couple has not made a pre-nuptial agreement in property (Melisiyani, 2018). However, if someone wants to marry a foreigner under Indonesian Marriage Law, they must be informed of several obstacles and prohibitions in terms of a foreigner owning the assets. Therefore, it would be better for the mixed marriage couples to plan the separation agreement before celebrating the marriage. A separation agreement in the asset is required for a mixed marriage. Thus, every people who are interested in marrying an Indonesian must consider it.

Challenges in the implementation of the Constitutional Court Decision No. 69/PUU/XII/2015 will also be present in the future. It would be a challenge to the 


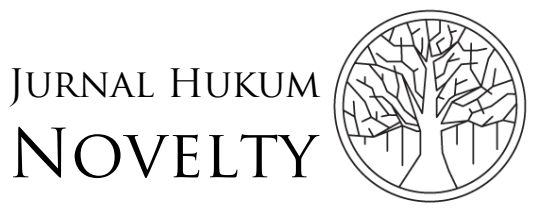

Volume 12, Issue 02, 2021, pp. 282-294

P-ISSN: $1412-6834$

E-ISSN: 2550-0090

government in the context of family law. Several potential problems in the context of marriage agreement are (Rowan, 2018): (1) during the marriage, (2) third party involvement. It needs to be understood that the implementation of the Constitutional Court Decision applies to all citizens, not only for mixed marriage actors. Thus, every marriage actor is possible to create a marriage agreement during the marriage. The word "during" is interpreted as marriage couple with bad intentions to trick the third party involved by creating a marriage agreement (Sanjaya \& Kuswara, 2018).

For example:

First, there is a couple, husband $(\mathrm{X})$ and wife $(\mathrm{Y}), \mathrm{Y}$ is a businessman, and she has many contacts with other people (companies). In their marriage life, they acquire a house and land during the marriage. Based on Indonesian marriage law, it would be considered as communal ownership because Indonesia applies unification of assets (Setyaningsih, 2020). Several years later, Y entered into a debt financing agreement with a bank, and the bank requested her house to be the collateral that is needed to activate the mortgage agreement. It is to be known that the house which is submitted as collateral in the bank is a joint asset. In the performance of the contract, Y gave her own rights toward the house to her husband. It means that the house is then the husband's property. Bank, as the third party was not involved nor did they know everything, and it was possible for them to suffer losses.

Second, husband (A) and wife (B), A, have many businesses. He gained a lot of profit from his businesses. To build his business, he lent money from a finance company until his businesses were well-managed. Several years later, he predicted that his businesses would suffer losses because of his error in marketing strategy. Before he suffered the probable losses, he agreed with his wife to separate their assets during the marriage. Mostly the assets are entitled to his wife, including the house, land, and everything, he was left with owning only one car. When the losses came, he declared the bankruptcy of his business. The third party requested him to sell his assets to repay the collateral debt made before. He responded that he had no assets left, only one vehicle.

From the examples of the cases above, there is a potential for loss received by a third party. It means that to implement the marriage agreement during the marriage, it needs careful attention of the government to prevent the similar aforementioned smuggling of the law from repeating in the future (Elko, 2015). The marriage agreement has several objectives in practice (Walker, 2015):

1. Separating the assets between husband and wife has the consequence that their assets are authorized or owned by an individual party. If a divorce takes place, the assets follow the initial owner.

2. It also has an impact on the debt of the individual party. Each party should be responsible for its debt.

3. Each party has no obligation to ask permission from the other if they wish to sell their assets. 
4. Each party has no obligation to ask permission from the other if they wish to lend their money, submit their assets as collateral, and other obligations related to debt.

\section{Those Challenges Should be Addressed in Technical Rules and Specific Format to be Implemented}

To choose between challenges or hopes, both have their characteristics in interpreting the Constitutional Court Decision. In every hope, there is always a challenge to overcome, likewise in implementing the post-nuptial agreemen (Sörgjerd, 2012). However, those challenges can be minimized by reducing the potential problems stated before, such as (Mosberg \& Kindregan, 2019): (1) by making the technical arrangements; and (2) by making the specific format of the agreement. For example, the technical arrangements can regulate that the underlying rationale should not be for the simple reasons because post-nuptial agreement applies to all Indonesian citizens and not to mixed marriage actors. Thus, it would be better if it is duly regulated. The financial condition is also worth re-checking, such as the condition of probable or current bankruptcy. The parties to the post-nuptial agreement should declare their properties, especially the properties which are subjected as collateral to the third party. It means that those technical arrangements are to be made to examine the good faith of the parties (Sanjaya, 2019).

The specific format is also a matter of urgency to be realized in the post-nuptial agreement. The format should be released and registered by the authorized institution (Widyadi, 2019). It means that the format has already determined the points or model of the post-nuptial agreement (Werdiningsih et al., 2020). It is crucial to keep the ethic, norms, and values of justice toward the affiliated party. Afterward, that post-nuptial agreement is proposed to the court to be examined and released in the formal court decision. In the making of this post-nuptial agreement, it should be linked to the proposal of adoption in the court decision or guardianship court decision. It means that the making of a post-nuptial agreement involves the judicial institution, which also means publication by the court (Cuadra, 2012). The court decision will serve the truth and justice before the law in realizing post-nuptial agreement. Also, if their properties are subjected to collateral, the court can declare the legal status of such properties or at least consider that the properties belong to a third party (Judiasih, 2017).

\section{Conclusion}

Constitutional Court Decision serves a hope in the perspective of family law in Indonesia. The hope is in the shape of possibilities of mixed marriage to make a postnuptial agreement in separating the properties. It is a solution offered to mixed marriage couples, especially for foreigners. Thus, they do not have to change their nationality. However, this hope still leads to a potential problem in the law. It is a challenge for the government to facilitate the technical arrangement and designated format for post-nuptial agreement. Also, judicial involvement is needed to check and examine the application of post-nuptial agreement before the court to be declared in 
a formal court decision. Therefore, the post-nuptial agreement becomes part of the judicial decision as well as an adoption or guardianship decision. However, the hope from the Constitutional Court Decision is more helpful toward mixed marriage couples in the future, although it cannot be completely perfect in the implementation. It always generates more challenges, such as local marriage couples. The potential problem is if such agreement to separate the assets is made during the marriage and do not pay attention to the existence of a third party.

\section{Acknowledgment}

The authors would like to thank Universitas Islam Indonesia for the resources provided to conduct this research publication. Sincere gratitude also goes to anonymous reviewers and editors who have provided constructive feedback so that this manuscript looks worth reading and citing.

\section{Declarations}

Author contribution : Initiated the research ideas, instrument construction, data collection, analysis, draft writing, revised the research ideas, literature review, data presentation and analysis, and the final draft.

Funding statement : This research is funded by the author.

Conflict of interest : The author declares no conflict of interest.

Additional information : No additional information is available for this paper.

\section{References}

Amruzi, Fahmi Al. 2014. Hukum Harta Kekayaan Perkawinan. Yogyakarta: Aswaja press.

Andriani, Dian, Bambang Santoso, and Oksidelfa Yanto. 2020. "Pemisahan Harta Perkawinan Campuran Dan Akibat Hukumnya Jika Diwariskan Tanpa Wasiat Pada Anak Berkewarganegaraan Ganda." Jurnal Lex Specialis 1 (1): 61-70. http://openjournal.unpam.ac.id/index.php/jlsp/article/view/6501.

Anjasari, Lulu. 2018. "MK: Perjanjian Perkawinan Dapat Dilakukan Selama Masa Perkawinan.” 2018. https://www.mkri.id/index.php?page=web.Berita\&id=13415\&menu=2.

Anwar, Syamsul. 1999. "Perjanjian Dalam Islam, Kajian Terhadap Masalah Cacat Kehendak (Wilsgebereken)." Jurnal Penelitian Agama Januari-Ap (21).

Arikunto, Suharsimu. 1996. Prosedur Penelitian Suatu Pendekatan Praktek. Jakarta: Rineka Cipta.

Budiartha, I Nyoman Putu. 2017. “Dilema Penegakan Hukum Putusan MK No.69/PUUXII/2015 (Persoalan Perkawinan Campuran Tanpa Perjanjian Kawin)." Jurnal Notariil 1 (2): 1-12. https://doi.org/10.22225/jn.2.1.151.1-12.

Clarke, Elliabeth Cooke, and Spencer. 2014. "The Law Commission's Report on Matrimonial Property, Needs and Agreements." Family Law Quarterly 48 (2): 14.

Cuadra, Bernardo G. 2012. "All Good Things Might Come to An End: Postnuptial Agreements in Connecticut.” Western New England Law Review's 34 (1): 57-143. 
https://digitalcommons.law.wne.edu/lawreview/vol34/iss1/3/.

Djasadin Saragih. 1974. Dasar-Dasar Hukum Perdata Internasional. Bandung: Alumni. Elko, Sharai. 2015. "Alimony Provisions in Premarital, Postnuptial, and Separation Agreements." Journal Contemporary Legal Issues 93.

Gautama, Sudargo. 1995. Hukum Perdata Internasional, Jilid II, Bagian I, Buku Ke-7. Bandung: Alumni.

Harahap, M. Yahya. 2007. Kedudukan Kewenangan Dan Acara Peradilan Agama, Jakarta: Sinar Grafika.

Harahap, Sayaman. 2016. "Penerapan Ketentuan Pasal 21 Ayat (3) UUPA Tentang Kepemilikan Tanah Bagi WNI Dalam Perkawinan Campuran." Jurnal IUS Kajian Hukum Dan Keadilan 4 (3): 436. https://doi.org/10.29303/ius.v4i3.328.

Hernoko, Agus, Erni Agustin, Faizal Kurniawan, and Mahendri Putri. 2018. "Nuptial Agreement in Indonesia: A New Change in Indonesian Marriage Law" 131 (1): 24-27. https://doi.org/10.2991/iclgg-17.2018.4.

Ismail, Didi Jubaidi, and Maman Abdul Djaliel. 2000. Membina Rumah Tangga Islami Di Bawah Ridha Allah. Bandung: Pustaka Setia.

Judiasih, Sonny Dewi. 2017. "Pertaruhan Esensi Itikad Baik Dalam Pembuatan Perjanjian Kawin Pasca Putusan Mahkamah Konstitusi Nomor 69/PUU-XIII/2015." Jurnal Notariil 1 (2): 68-88. https://doi.org/10.22225/jn.2.1.179.68-83.

Lawrence Li. 2014. "Be Prepared in Advance : A Case for Allowing Binding Prenuptial Agreement in Hongkong." International Journal of Law, Policy and the Family 28 (3): 23. https://doi.org/https://doi.org/10.1093/lawfam/ebu003.

Lemmings, David. 1996. "Marriage and the Law in the Eighteenth Century: Hardwicke's Marriage Act of 1753." Historical Journal 39 (2). https://doi.org/10.1017/S0018246X00020276.

Mamudji, Sri. 2005. Metode Penelitian Dan Penulisan Hukum. Jakarta: Badan Penerbit Fakultas Hukum Universitas Indonesia.

Manan, Abdul, and M. Fauzan. 2000. Pokok-Pokok Hukum Perdata Wewenang Peradilan Agama. Jakarta: PT. Raja Grafindo Persada.

Melisiyani, Dwi Putri. 2018. "Studi Komparatif Tentang Perjanjian Perkawinan Sebelum Dan Sesudah Adanya Putusan Mahkamah Konstitusi Nomor 69/PUU-XIII/2015." Jurnal Fatwa Hukum 1 (2). https://jurnal.untan.ac.id/index.php/jfh/article/view/25378/0.

Mosberg, By Michael A, and Patricia Kindregan. 2019. "Ten Practice Tips for Postnuptial Agreements : Drafting Considerations and Formalities." Family Law Quarterly 52 (2).

Mubarok, Ahmad Fiter. 2018. "Implikasi Putusan MK Dalam Perkawinan Campuran Di KUA Lelea Kabupaten Indramayu (Studi Putusan MK No. 69/PUU/XII/2015 Dan Surat Edaran Dukcapil No. 472.2/5876/DUKCAPIL." Universitas Islam Indonesia. https://dspace.uii.ac.id/handle/123456789/8110.

Muttaqin. 2003. Pedoman Pegawai Pencatat Nikah (PPN ). Jakarta: Departemen Agama RI. 
Rowan, Eleanor. 2018. "A 'Thorne' in the Side for Family Lawyers in Australia: Undue Influence and Prenuptial Contracts." Journal of Social Welfare and Family Law 40 (2): 238-40. https://doi.org/10.1080/09649069.2018.1451024.

Sanjaya, Umar Haris. 2019. "Good Faith on Contract Performance." Arena Hukum 12 (3): 500-523. https://doi.org/10.21776/ub.arenahukum.2019.01203.6.

Sanjaya, Umar Haris, and Tedy Kuswara. 2018. "Implementation of Personality Principle in the Termination of Village Ground Treasure Utilization No. 143/1728 Between PB. Rancah Karya and Catur Tunggal Village Government." SHS Web of Conferences 54. https://doi.org/10.1051/shsconf/20185406002.

Setyaningsih, Ni Putu Ari. 2020. "Akibat Hukum Pembuatan Perjanjian Perkawinan Setelah Perkawinan Berlangsung Terhadap Utang Bersama.” Yustitia 14 (2). https://www.ojs.unr.ac.id/index.php/yustitia/article/view/499.

Sörgjerd., Caroline. 2012. Reconstructing Marriage : The Legal Status of Relationships in a Changing Society. First edit. England: Intersentia.

Tjitrosudibio, R. Subekti dan R. 2009. Kitab Undang-Undang Hukum Perdata. Jakarta: Balai Pustaka.

Timex, Hendhy, Suhariningsih, and Rachmi Sulistyarini. 2015. "Pokok-Pokok Agraria.Pembuatan Dan Pengesahan Perjanjian Perkawinan Antara Melalui Penetapan Pengadilan Dan Notaris Pasca Putusan Mahkamah Konstitusi Nomor 69/PUU-XIII/2015." Jurnal Ilmiah Pendidikan Pancasila Dan Kewarganegaraan (JIPPK) 13 (3): 1576-80.

Umar Haris Sanjaya, Aunur Rahim Faqih. 2017. Hukum Perkawinan Islam Di Indonesia. Gama Media. Vol. 46.

Walker, Laura M. 2015. Family Law and Public Policy. Alphen aan den Rijn: Wolters Kluwer Law \& Business.

Werdiningsih, Rato, Dominikus, M Khoidin, and Aries Harianto. 2020. "Marriage Agreement During Marriage (A Postnuptial Agreement) Principle of Publicity as a Legal Protection for Creditors." Journal of Law, Policy and Globalization 101: 129-40. https://doi.org/10.7176/jlpg/101-14.

Widyadi, Made. 2019. "Authority of Notary and the Power of Law Postnuptial Agreement Deed Post-Decision of Constitutional Court." Jurnal Notariil 4 (1): 27 37. https://doi.org/https://doi.org/10.22225/jn.4.1.749.27-37. 